Al-Tanzim : Jurnal Manajemen Pendidikan Islam

E-ISSN: 2549-5720 P-ISSN: 2549-3663

March 2019, Vol. 03 No. 01, p. 156-168

https:// ejournal.unuja.ac.id/index.php/al-tanzim

\title{
KOMPETENSI MANAJERIAL KONSELOR PADA LAYANAN KONSELING KELOMPOK
}

\author{
Dody Riswanto \\ Universitas Mathla'ul Anwar Banten \\ ronaldody32@gmail.com
}

\begin{abstract}
:
The purpose of this study was to determine the managerial ability of the counselor in implementing group counseling at school. The research method used is qualitative, data analysis used is drawing conclusions based on Lawrence's theory. The results of the research and discussion are conflict, resistance, confrontation and imbalance of group members as the main problems in group dynamics, the managerial ability of the counselor in organizing, leading, directing and organizing all group members to be successful indicators of group counseling success.
\end{abstract}

Key words : Managerial, Counselor, Group Counseling

\section{Abstrak :}

Tujuan penelitian ini adalah untuk mengetahui kemampuan manajerial konselor pada pelaksanaan konseling kelompok di sekolah. Metode penelitian yang digunakan adalah kualitatif, analisis data yang digunakan adalah penarikan kesimpulan berdasarkan teori Lawrence. Hasil penelitian dan pembahasan adalah konflik, resistensi, konfrontasi dan ketidakseimbangan anggota kelompok menjadi permasalahan utama dalam dinamika kelompok, kemampuan manajerial konselor dalam mengatur, memimpin, mengarahkan dan mengorganisasikan semua anggota 
Al-Tanzim : Jurnal Manajemen Pendidikan Islam

E-ISSN: 2549-5720 P-ISSN: 2549-3663

March 2019, Vol. 03 No. 01, p. 156-168

https:/ / ejournal.unuja.ac.id/ index.php/ al-tanzim

kelompok menjadi indikator sukses keberhasilan konseling kelompok.

Kata Kunci : Manajerial, Konselor, Konseling Kelompok

\section{PENDAHULUAN}

Konseling kelompok adalah pemberian bantuan kepada peserta didik yang difasilitasi oleh konselor dengan tujuan agar peserta didik sebagai anggota kelompok dapat menyelesaikan tugas perkembangannya secara maksimal baik secara akademis, maupun pribadi sosialnya.

Konselor sebagai seorang pendidik merupakan salah satu tenaga kependidikan di sekolah yang memiliki keahlian dalam bidang bimbingan dan konseling, konselor memiliki keahlian dalam melaksanakan layanan psikopedagogis yang memiliki peran memfasilitasi dan membawa manusia berkembang dari kondisi apa adanya atau what it is menjadi bagaimana seharusnya atau what should be (Hartono dan Soedarmadji, 2012)

Pelaksanaan konseling kelompok dapat dicapai tentunya dengan kemampuan konselor yang memiliki kompetensi mumpuni, diantara kompetensi tersebut adalah kompetensi pribadi yang didalamnya memuat tentang kemampuan manajerial.

Landasan utama dalam memilih program konseling kelompok adalah melatih kemampuan manajerial konselor kepada peserta didik, konseling kelompok dinilai ideal 
Al-Tanzim : Jurnal Manajemen Pendidikan Islam

E-ISSN: 2549-5720 P-ISSN: 2549-3663

March 2019, Vol. 03 No. 01, p. 156-168

https:/ / ejournal.unuja.ac.id/ index.php/ al-tanzim

dibanding peserta didik yang berada dalam ruangan kelas disebabkan ketidakpastian konselor mendapatkan jadwal jam pelayanan untuk masuk kedalam ruangan kelas.

\section{KAJIAN PUSTAKA}

Kajian penelitian ini memiliki nilai urgensi yang sangat penting. Landasannya adalah bahwa untuk melatih konselor sebagai pemimpin kelompok adalah termasuk topik penelitian yang paling sedikit dipelajari (Zipora, 2014). Konselor harus memiliki pelatihan yang memadai tentang konseling kelompok serta mendorong agar pengetahuan, pengalaman, dan supervisi di dalam konseling kelompok dapat menjadi titik fokus dalam pengembangan kepribadian pemimpin kelompok (Sarah, 2015).

Kepemimpinan konselor dalam memanajerial proses konseling kelompok diantaranya adalah kemampuan untuk mengintervensi. Konselor dapat melakukan intervensi pada anggota kelompok berkenaan dengan kondisi dan situasi krisis yang dihadapi oleh anggota kelompok, utamanya perasaan takut yang dapat mengganggu jalannya proses konseling kelompok (Sigit, 2010).

Keterampilan manajerial konselor lainnya adalah bagaimana konselor mampu untuk menyeimbangkan dan menyelaraskan anggota kelompok. Konselor harus mampu mencapai keseimbangan untuk menegaskan kepemimpinan dan menciptakan lingkungan yang aman dan ramah bagi 
Al-Tanzim : Jurnal Manajemen Pendidikan Islam

E-ISSN: 2549-5720 P-ISSN: 2549-3663

March 2019, Vol. 03 No. 01, p. 156-168

https:/ / ejournal.unuja.ac.id/ index.php/ al-tanzim

anggota kelompok, pemimpin kelompok yang efektif adalah seorang komunikator handal dan lemah lembut yang memiliki keterampilan mendengarkan serta menafsirkan kebutuhan dan perasaan anggota kelompok (Hannah, 2018).

\section{METODE PENELITIAN}

Metode yang digunakan dalam penelitian ini adalah pendekatan kualitatif, penelitian kualitatif adalah usaha seorang peneliti dalam memahami bagaimana satu atau lebih individu mengalami fenomena tertentu, dengan menggunakan eksplorasi metode ilmiah dalam menghasilkan temuan sementara dan mengembangkan pemahaman tentang manusia, tempat, dan kelompokkelompok tertentu (Johnson dan Larry, 2014)

Lokasi penelitian dilaksanakan di sebuah perguruan tinggi Islam di kabupaten Pandeglang, yaitu Universitas Mathla'ul Anwar Banten, subyek penelitian adalah mahasiswa bimbingan dan konseling semester IV dengan jumlah 6 orang subyek atau mahasiswa, waktu penelitian dilaksanakan selama satu semester pada mata kuliah konseling kelompok pada semester genap bulan Maret-Juni tahun 2019 yang diampu oleh peneliti.

Teknik pengumpulan data yang digunakan adalah pengamatan atau observasi, wawancara, dan studi dokumentasi. Peneliti kualitatif wajib mengumpulkan datadata penting seperti wawancara, observasi, dokumen, dan 
Al-Tanzim : Jurnal Manajemen Pendidikan Islam

E-ISSN: 2549-5720 P-ISSN: 2549-3663

March 2019, Vol. 03 No. 01, p. 156-168

https:/ / ejournal.unuja.ac.id/ index.php/ al-tanzim

informasi audio visual (Creswell, 2014). Peneliti berperan sebagai instrumen kunci dalam penelitian ini.

Analisis data yang digunakan dalam penelitian ini menggunakan beberapa langkah dan tahapan, diantaranya adalah pemeriksaan, pemilahan, kategorisasi, evaluasi, membandingkan, men-sintesis, dan menafsirkan kode dan data serta meninjau data-data mentah yang telah direkam (Lawrence, 2014).

\section{HASIL PENELITIAN DAN PEMBAHASAN}

Konselor wajib memiliki kompetensi-kompetensi tertentu agar dapat melaksanakan tugasnya dengan baik (Riswanto, 2017). Konselor wajib menampilkan kinerja yang berkualitas tinggi, artinya adalah konselor mengadopsi nilai-nilai ini dengan menampilkan kinerja berkualitas tinggi berdasarkan pada tindakan yang cerdas, kreatif, inovatif dan produktif (Riswanto, 2016).

Kualitas karakteristik kepribadian konselor jelas memiliki pengaruh terhadap pemahaman peserta didik di sekolah (Riswanto, 2019). Kualitas kompetensi kepribadian yang ditampilkan oleh konselor dapat mempengaruhi hasil akhir atau bahkan keseluruhan dari rangkaian pelaksanaan konseling kelompok, spesifikasi dari kompetensi tersebut adalah kemampuan manajerial konselor dalam konseling kelompok. 
Al-Tanzim : Jurnal Manajemen Pendidikan Islam

E-ISSN: 2549-5720 P-ISSN: 2549-3663

March 2019, Vol. 03 No. 01, p. 156-168

https:/ / ejournal.unuja.ac.id/ index.php/ al-tanzim

Kemampuan manajerial konselor menjadi suatu permasalahan yang kondisional mengingat posisi konselor sebagai pemimpin kelompok dalam pelaksanaan konseling kelompok itu sendiri, hal ini berlandaskan pada kenyataan di lapangan bahwa tidak sedikit pelaksanaan konseling kelompok yang gagal akibat kemampuan manajerial konselor yang kurang atau bahkan tidak ada sama sekali.

Kemampuan manajerial konselor dalam konseling kelompok terdiri dari 4 bagian yaitu mengatur, memimpin, mengarahkan dan mengorganisasikan anggota kelompok, kemampuan manajerial konselor dilihat berdasarkan 4 tahapan dalam pelaksanaan sesi konseling kelompok, yaitu tahap pembentukan, tahap peralihan, tahap kegiatan dan tahap pengakhiran, pada masing-masing tahap atau fase tersebut kinerja manajerial konselor dinilai dan dievaluasi untuk menemukan celah permasalahan pada bagian mana yang kurang dan pada bagian mana yang harus ditambahkan.

\section{MANAJERIAL KONSELOR PADA TAHAP PEMBENTUKAN}

Tahap pembentukan adalah awal mula pra-kegiatan konseling kelompok yang diawali dengan pengenalan masing-masing anggota kelompok, perkenalan diri masingmasing anggota kelompok ditujukan karena sebagian besar anggota kelompok tidak saling mengenal satu sama lain, 
Al-Tanzim : Jurnal Manajemen Pendidikan Islam

E-ISSN: 2549-5720 P-ISSN: 2549-3663

March 2019, Vol. 03 No. 01, p. 156-168

https:/ / ejournal.unuja.ac.id/ index.php/ al-tanzim

agar anggota kelompok dapat saling mengenal dan akrab maka pengenalan diri menjadi langkah wajib pada awal tahap pembentukan.

Kemampuan manajerial konselor dalam mengatur, memimpin, mengarahkan dan mengorganisasikan anggota kelompok dimulai saat terjadinya permasalahan pada anggota kelompok, masalah mulai muncul saat beberapa anggota kelompok mulai pasif berbicara, anggota kelompok hanya diam dan tidak berani berkomunikasi.

Tugas konselor sebagai pemimpin kelompok dalam memanajerial anggota kelompok yang pasif tersebut adalah dengan mengatur bagaimana anggota kelompok dapat kembali aktif berkomunikasi, langkahnya bisa dengan mengorganisasikan seluruh anggota kelompok untuk membuat ice breaking agar ketegangan sesama anggota kelompok dapat dihilangkan.

Langkah berikutnya bisa dengan mengarahkan anggota kelompok yang pasif tersebut untuk memulai berkomunikasi setelah konselor mengambil alih kelompok terlebih dahulu dan memberikan kesempatan kepada anggota kelompok yang terlihat pasif dan tidak berani berbicara, langkah ini diambil disebabkan karena dominasi beberapa anggota kelompok yang terlalu banyak berbicara sehingga membuat anggota kelompok yang lain tidak memiliki kesempatan yang sama untuk mengutarakan permasalahannya. 
Al-Tanzim : Jurnal Manajemen Pendidikan Islam

E-ISSN: 2549-5720 P-ISSN: 2549-3663

March 2019, Vol. 03 No. 01, p. 156-168

https:/ / ejournal.unuja.ac.id/ index.php/ al-tanzim

\section{MANAJERIAL KONSELOR PADA TAHAP PERALIHAN}

Tahap peralihan adalah tahap kedua setelah tahap pembentukan yang dicirikan dengan terbentuknya struktur kelompok yang solid pada tahap pertama, pada tahap ini masalah kelompok terlihat secara jelas sebagai bagian dari dinamika kelompok yang dihadapi, ketidakseimbangan dalam diri masing-masing anggota kelompok muncul sebagai masalah utama yang harus segera diselesaikan, wujud ketidakseimbangan tersebut diantaranya adalah konflik, resistensi, kecemasan, enggan membuka diri dan beberapa unsur ketidakseimbangan lainnya.

Tugas konselor sebagai pemimpin kelompok dalam memanajerial anggota kelompok yang berkonflik dimulai dengan beberapa langkah dan strategi, diantaranya adalah meningkatkan minat anggota terhadap proses konseling kelompok yang berlangsung, konselor mengontrol dan mengarahkan setiap anggota kelompok agar bisa meningkatkan minat dan gairah dalam keanggotaan kelompok.

Langkah berikutnya adalah bagaimana konselor memanajerial para anggota kelompok dengan memotivasi mereka dengan sugesti positif, anggota kelompok harus dihargai, diberi penghargaan, diberikan reward, diyakinkan baik secara fisik dan mental bahwa mereka sanggup dan bisa untuk mengatasi permasalahan tersebut, sugesti positif 
Al-Tanzim : Jurnal Manajemen Pendidikan Islam

E-ISSN: 2549-5720 P-ISSN: 2549-3663

March 2019, Vol. 03 No. 01, p. 156-168

https:/ / ejournal.unuja.ac.id/ index.php/ al-tanzim

dan optimisme yang tinggi benar-benar harus ditekankan oleh konselor pada langkah ini.

\section{MANAJERIAL KONSELOR PADA TAHAP KEGIATAN}

Tahap kegiatan adalah tahap inti diantara seluruh empat tahap konseling kelompok, pada tahap ini seluruh anggota kelompok telah siap untuk mengikuti kegiatan inti dan suasana hubungan antar anggota kelompok seharusnya sudah harmonis dan solid, masalah muncul ketika terdapat beberapa anggota kelompok yang mendominasi seluruh kegiatan kelompok yang tengah berlangsung, pada tahap ini masing-masing anggota dibebaskan untuk mengemukakan ide, pendapat, kreasi, masukan, pendangan dan solusi tanpa adanya dominasi beberapa anggota kelompok yang terlihat dominan.

Manajerial konselor dalam mengatasi masalah ini dimulai dengan beberapa langkah dan tahapan, diantaranya adalah konselor mengambil alih rangkaian kegiatan kelompok yang tengah berlangsung untuk melakukan intervensi secara langsung, konselor dapat membuat keputusan secara mutlak mengenai keanggotaan beberapa anggota kelompok yang dominan dan cenderung menjadi konflik bagi anggota lainnya.

Konselor dapat mengarahkan dan juga memimpin anggota kelompok yang dominan tersebut dengan beberapa langkah dan strategi yang telah ditentukan sebelumnya, 
Al-Tanzim : Jurnal Manajemen Pendidikan Islam

E-ISSN: 2549-5720 P-ISSN: 2549-3663

March 2019, Vol. 03 No. 01, p. 156-168

https:/ / ejournal.unuja.ac.id/ index.php/ al-tanzim

agar dapat memberikan kesempatan bagi anggota kelompok yang lain untuk mengutarakan masalah dan pendapatnya masing-masing, konselor harus memimpin setiap anggota kelompok untuk menentukan sendiri topik permasalahan, pembahasannya, dan solusinya serta mengorganisasikan seluruh anggota agar dapat mengemukakan ide, kreasi, dan pandangannya terhadap permasalahan yang dihadapi.

\section{MANAJERIAL KONSELOR PADA TAHAP AKHIR}

Pada tahap ini seluruh rangkaian kegiatan kelompok akan segera diakhiri dan diselesaikan, setiap keputusan solusi permasalahan telah ditentukan oleh masing-masing anggota kelompok, setiap anggota kelompok harus memulai perubahan tingkah laku dan menilai sejauh mana keberhasilan kelompok dalam menyelesaikan permasalahan setiap anggota.

Manajerial konselor pada tahap akhir ini adalah mengarahkan dan mengorganisasikan seluruh anggota kelompok untuk berkomitmen mengubah tingkah laku sesuai dengan keputusan yang telah ditentukan, hal ini dilakukan utamanya pada beberapa anggota kelompok yang merasa tidak yakin dan menilai terjadinya kegagalan dalam proses konseling kelompok, sugesti positif dari konselor agar semua anggota kelompok dapat berkomitmen bersama untuk mengubah tingkah laku adalah sebuah kewajiban. 
Al-Tanzim : Jurnal Manajemen Pendidikan Islam

E-ISSN: 2549-5720 P-ISSN: 2549-3663

March 2019, Vol. 03 No. 01, p. 156-168

https:/ / ejournal.unuja.ac.id/ index.php/ al-tanzim

Manajerial konselor berikutnya adalah mengingatkan anggota kelompok untuk membuat jadwal pertemuan pada konseling kelompok berikutnya, konselor harus memimpin bagaimana setiap anggota kelompok dapat memberikan kesan dan pesan serta menilai keberhasilan konseling kelompok bagi semua anggota kelompok, konselor dapat membuat evaluasi dan follow up terhadap seluruh rangkaian kegiatan konseling kelompok.

\section{KESIMPULAN}

Keberhasilan dan kesuksesan konseling kelompok salah satunya adalah ditentukan dengan kemampuan manajerial yang dimiliki oleh konselor, hal ini berlandaskan pada dinamika kelompok yang terjadi yang berujung pada konflik dan ketidakseimbangan struktur kelompok, karena itu konselor mengambil alih dan memanajerial dinamika kelompok yang terjadi agar dapat menyeimbangkan kembali struktur kelompok agar lebih solid dan harmonis.

Kemampuan manajerial konselor ditentukan oleh 4 faktor yaitu bagaimana konselor mengatur, memimpin, mengarahkan dan mengorganisasikan seluruh anggota kelompok pada tahap pembentukan, tahap peralihan, tahap kegiatan dan tahap akhir dan memastikan keberhasilan konseling kelompok yang dapat dirasakan manfaatnya bagi semua anggota kelompok. 
Al-Tanzim : Jurnal Manajemen Pendidikan Islam

E-ISSN: 2549-5720 P-ISSN: 2549-3663

March 2019, Vol. 03 No. 01, p. 156-168 https:/ / ejournal.unuja.ac.id/ index.php/ al-tanzim

\section{DAFTAR PUSTAKA}

Bali, M. M. E. I. (2018). Strategi Pembelajaran Pendidikan Agama Islam. Probolinggo: Pustaka Nurja.

Creswell, John W. (2014). Research Design: Qualitative,

Quantitative and Mixed Methods Approaches-Fourth Edition. Los Angeles: Sage Publications, Inc.

Fajri, Z. (2018). BAHAN AJAR TEMATIK DALAM PELAKSANAAN KURIKULUM 2013. Jurnal Pedagogik, 5(1), 100-108.

Hartono dan Soedarmadji. (2012). Psikologi Konseling Edisi Revisi. Jakarta: Kencana Prenada Media Group.

Hefniy. (2016). Kyai Leadership in Improving Organizational PErformance in Pesantren. Proceeding, 2nd ICET Theme:"IMPROVING THE QUALITY OF EDUCATION AND TRAINING THROUGH STRENGTHENING NETWORKING," 324.

Johnson, R Burke. Christensen, Larry. (2014). Educational Research: Quantitative, Qualitative, and Mixed Approaches-Fifth Edition. Los Angeles: Sage Publications, Inc.

Neuman, W Lawrence. (2014). Social Research Methods: Qualitative and Quantitative Approaches-Seventh Edition. London: Pearson Education Limited. 
Al-Tanzim : Jurnal Manajemen Pendidikan Islam

E-ISSN: 2549-5720 P-ISSN: 2549-3663

March 2019, Vol. 03 No. 01, p. 156-168

https:// ejournal.unuja.ac.id/index.php/al-tanzim

Riswanto, Dody. Mappiare-AT, Andi. Irtadji, M. (2016).

Karakteristik Kepribadian Ideal Konselor (Studi Hermeneutika Gadamerian). Jurnal Pendidikan: Teori, Penelitian, dan Pengembangan, 1(11), 2113-2117.

Riswanto, Dody. Mappiare-AT, Andi. Irtadji, Mohammad. (2017). Kompetensi Multikultural Konselor Pada Kebudayaan Suku Dayak Kalimantan Tengah. JOMSIGN: Journal of Multicultural Studies in Guidance and Counseling, 1(2), 215-226.

Riswanto, Dody. (2019). Penguatan Nilai-nilai Pancasila dan Kebangsaan Kepada Peserta Didik Pada Layanan Bimbingan dan Konseling di Sekolah. Jurnal Civic Education, 3(1), 13-19.

Sanyata, Sigit. (2010). Teknik dan Strategi Konseling Kelompok. Jurnal Paradigma, 5(9), 105-120.

Shechtman, Zipora. (2014). Group Counseling In The School. Journal of Psychology, 11(1), 169-183.

Springer, Sarah. (2015). Aspects of Site Supervision as Predictors of Group Leader Selfefficacy for PreService School Counselors. Dissertation. Montclair State University.

Wahlig, Hannah. (2018). Leadership Skills and Strategies for Group Counseling. https://careertrend.com/info7840061-leadership-skills-strategies-group-counseling html. 